\title{
Miranda
}

Revue pluridisciplinaire du monde anglophone /

Multidisciplinary peer-reviewed journal on the English-

speaking world

13 | 2016

Thomas Spence and his Legacy: Bicentennial

Perspectives

\section{Thomas Spence : Literary networks and connections. Daniel Isaac Eaton, Hannah More, and Ralph Beilby}

\section{Edmund Downey}

\section{(2) OpenEdition \\ Journals}

Electronic version

URL: http://journals.openedition.org/miranda/9235

DOI: 10.4000/miranda.9235

ISSN: 2108-6559

Publisher

Université Toulouse - Jean Jaurès

\section{Electronic reference}

Edmund Downey, "Thomas Spence : Literary networks and connections. Daniel Isaac Eaton, Hannah More, and Ralph Beilby", Miranda [Online], 13 | 2016, Online since 17 November 2016, connection on 16 February 2021. URL: http://journals.openedition.org/miranda/9235 ; DOl: https://doi.org/10.4000/ miranda.9235

This text was automatically generated on 16 February 2021.

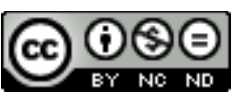

Miranda is licensed under a Creative Commons Attribution-NonCommercial-NoDerivatives 4.0 International License. 


\title{
Thomas Spence : Literary networks and connections. Daniel Isaac Eaton, Hannah More, and Ralph Beilby
}

\author{
Edmund Downey
}

1 Thomas Spence's publications and political activities are currently the subject of renewed interest. ${ }^{1}$ His works are attracting fresh critical attention and, importantly, David Gardner-Medwin and Alistair Bonnett have recovered the original publication of Property in Land Every One's Right (1775), which documents the origin of Spence's plan for land reform. ${ }^{2}$ Alongside this recent reassessment of Spence's work, I believe an examination of his connections can shed new light on the print networks that supported his career. This article examines Spence's connections with contemporary authors and political activists. Specifically, it examines Spence's relationship with the notable political reformer and fellow London Corresponding Society member Daniel Isaac Eaton (1753-1814) in the 1790s. It also considers the connections between Spence and conservative author Hannah More (1745-1833) a highly influential political figure whose professional connection with Newcastle printer Ralph Beilby (1744-1817) has recently been documented. ${ }^{3}$

2 I will begin by looking at the under-examined relationship between Eaton and Spence. Eaton has not suffered the same lack of attention that has side-lined Spence in some historical and literary criticism. E. P. Thompson recognised that Eaton's activities as a political printer (along with his seven prosecutions, three years of outlawry and eventual imprisonment in Newgate) were an essential part of the British reform movement. ${ }^{4}$ More recently Gregory Claeys has called Eaton "the most important radical publisher" operating in the 1790s. ${ }^{5}$ Eaton's name appears on numerous political publications in the 1790 s from his first foray into radical publishing in 1792, to his eventual outlawry and escape to America in $1797 .{ }^{6}$ It is evident that Eaton's publications played an integral part in shaping the reform movement during the 1790s.

3 Eaton's notoriety was due, in part, to the success of his political miscellany Hog's Wash, or a Salmagundy for Swine, later retitled simply Politics for the People (1793-1795). ${ }^{7}$ Eaton's 
magazine was a weekly periodical that took the form of collected extracts intended to enlighten and educate its readership on political matters. Politics for the People became a radical publication central to the reform movement that met with substantial popular success and helped to maintain, according to Daniel McCue, "the survival of a free press in England in the 1790s". ${ }^{8}$

Politics for the People also became the subject of a trial for sedition for publishing John Thelwall's speech 'King Chaunticlere ; or, the Fate of Tyranny'. ${ }^{9}$ Thelwall had indirectly compared the King to a tyrannical farmyard cockerel that was justly dispatched by a farmer for the benefit of the farm. The speech stretched the format of the animal fable as a mask for political satire to its limit and Eaton's printed version meant that he became a target for prosecution. ${ }^{10}$

Eaton was eventually acquitted. The result of the trial was celebrated in reform circles. Spence produced a commemorative token celebrating the event (see figure 1). ${ }^{11}$ On the halfpenny's obverse we have a profile of Eaton encircled by the words 'D. I. Eaton Three Times Acquitted for Sedition'. The caption under Eaton's profile reads 'Frangas Non Flectes' or, 'you may break me, but you shall not bend me'. This is a clear reference to Eaton's successful acquittal and his intentions to continue publishing in the face of prosecution. On the reverse is an image depicting the infamous scene that landed Eaton in court : a monarchical cockerel perching in an elevated position above the mud of the farmyard, where swine eat from a trough. Eaton's acquittal confirmed his place in the roster of radical celebrities.

Eaton's reputation as a radical publisher and advocate of democratic rights developed from the same print network that Spence worked in. This is most evident in the design and publication of Politics for the People. This magazine followed Spence's publishing success with his own political miscellany One Pennyworth of Pigs' Meat; or, Lessons for the Swinish Multitude (1793-1795). The structure and style of Eaton's magazine is very similar to the literary model which Spence had used in Pig's Meat. Examining such details allows us to reassess Eaton's work in the light of his connections to Spence, a figure seldom associated with his publishing. ${ }^{12}$

7 Pig's Meat was a weekly miscellany publication which offered political news and comment to a popular readership. The periodical features numerous authors and varied extracts on political thought. The extracts debate democracy, monarchy, political reform and widening access to literature. They include writings by William Frend, Joel Barlow and Constantin Francois Volney, as well as contributions from anonymous authors and radical pamphlets. Historical extracts comprise work by James Harrington, Algernon Sidney, Thomas More, John Milton, John Locke, and Jonathan Swift. The diversity of its radicalized extracts ensured that the publication lived up to its miscellany format.

8 Miscellany periodicals became popular during the mid-eighteenth century: one contemporary referred to the format as "the mince pyes of literature [...] where sweet, sour, sharp, and all the various modifications of taste are blended together to form one palatable Magazine". ${ }^{13}$ By the 1790s, miscellany publications such as the Gentleman's Magazine, the London Magazine, the Critical Review and the Monthly Review had become established and respected literary periodicals. It was into this publishing field that Spence launched Pig's Meat in 1793; he utilised the potential of the miscellany's heterogeneous content to provide affordable access to a vast array of radical material. 
In the 1790s Pig's Meat was the first magazine to adopt the miscellany format for radical use. Pig's Meat appeared in August 1793 and Eaton's Politics for the People was published in late September of the same year. Other radical miscellany magazines followed such as the Political Magazine (1794) the London Corresponding Society's Moral and Political Magazine (1796). Spence's magazine sold well. Figures indicate that Spence's Pig's Meat was being printed in the region of 1,500 copies per week. ${ }^{14}$ Monthly figures of 6,000 copies exceed the print runs of established periodicals such as The Monthly Review, The Monthly Magazine, The Gentleman's Magazine and The European Magazine, which were selling in the region of $3-5,000 .{ }^{15}$ This was the context into which Eaton launched Politics for the People.

The relationship between the two texts is evidenced by the opening letter of the first edition of Politics for the People. The letter is from 'A Brother Grunter', a pseudonym Spence used to write directly to Eaton. ${ }^{16}$ Spence is full of praise and adulation for Eaton's new literary endeavour :

Sir,

As a member of the Swinish Herd I beg leave to thank you for your diligence and attention in supplying us with good wholesome Food; on which I hope we shall long continue to feast ourselves, in spite of those who would wish to ring our Noses in order to prevent us from grubbing after Truth, or to starve us to death in the 'stye of Taxation'. But knowing that we are a very voracious species of animal, I was fearful least the provision should be devoured further than even your unremitting exertions might be able to supply it; I have therefore taken the liberty to send you a few morsels from a store of 'Hog's Meat' on which I lately made a repast, and found agreeable to the Swinish Palate of

Yours,

A Brother Grunter.

Hog's Town, September $9^{\text {th }}, 1793 .^{17}$

The letter reveals that Spence considered Eaton's new literary project to be similar to his own work, which is here referred to as "Hog's Meat". Spence offers his "Brother Grunter' a "few morsels" from his store of "good wholesome food". Eaton must have been keen to associate his new periodical with Pig's Meat to include Spence's letter as the opening article of the first edition. The formation and publication of Politics for the People therefore forms part of a direct literary association with Pig's Meat.

The link between Pig's Meat and Politics for the People was close enough for contemporary commentators to claim that Spence and Eaton were part of a joint project in the production of radical literature. Their names, coupled together, were used as shorthand for purveyors of illicit material and dangerous politics. A loyalist tract entitled The Malecontent (1794) bemoaned "the sort of trash that are bought at Eaton and Spence's, by poor people, who believe anything which they think seditious". ${ }^{18}$ Moreover, the two figures were cited together by such a prominent political figure as Charles Fox; in his 1807 memoir Fox quotes at length a description by the British diplomat Robert Adair of the dangerous political atmosphere of the 1790s. He recounts how "Spence and Eaton" began the "sale of pennyworth's of extracts of republican authors" in "Pig's Meat" and "Hog's Wash" and how "with such follies and vagaries were the labouring orders abused". ${ }^{19}$ The two periodicals, with their two radical editors, were remembered in the same breath.

13 Whilst it was commonplace for critics in the 1790s to group writers of apparently similar political persuasions together (the 'NEW SCHOOL' of radical poets identified by the Anti-Jacobin in 1797 is a prime example), in the case of Spence and Eaton they were 
also noting a deeply rooted connection. The similarity of Spence's magazine to Eaton's publication is clear. The original title Hog's Wash; or, A Salmagundy for Swine' is a reworking of Pig's Meat; or, Lessons for the Swinish Multitude'. The opening edition of Eaton's magazine also is also similar in content and visual design (see figure 2). The price, at one pence and two pence respectively advertises both periodicals as affordable to a common readership. The contents of Politics for the People are also similar to Spence's work. Indeed, the first extract is chosen by Spence. The extracts from Lord Lyttelton's Persian Letters (1735) provide pithy statements that are typical of Pig's Meat ; "To speak the Truth is the privilege of a Freeman, to do it roundly and plainly is his Glory". These statements set the tone and indicate the direction of Politics for the People. ${ }^{20}$ Eaton's magazine is full of similar miscellaneous extracts from contemporary and historical authors.

A close working relationship facilitated this interchange of ideas; the links between Spence and Eaton were personal as well as professional. Both men knew of each other through the London Corresponding Society and no doubt exchanged literary and political ideas. ${ }^{21}$ As well as producing commemorative coins recording Eaton's successes in the court room, Spence published a number of editions of Politics for the People during the former's stay in jail awaiting trial. ${ }^{22}$ It is therefore likely that a close relationship existed between the two men, one which resulted in Eaton using a similar literary template to produce Politics for the People. Acknowledging this close relationship with Eaton's helps to better position Spence as one the central figures of 1790s radicalism.

Spence, however, had more surprising connections. His prominence in British radical circles from the late eighteenth to the early nineteenth century results in an unlikely connection with the conservative author Hannah More. Spence was well known to More. Indeed, she personally attacked him in the period following the close of the Napoleonic Wars. ${ }^{23}$ Her 'Fair Words and Foul Meanings' (1818) opens with the following confrontation :

I'm a tradesman well known, though I boast not my wit,

I've too much by the Jacobin crew to be bit :

Now forget a while the foul doctrines of Spence

And hear my appeal to your sober good sense. ${ }^{24}$

16 The poem displays an awareness of Spence and the reputation of his radical politics. Spence's name was infamous in the 1810s. After the Spa Field riots an act of parliament had prohibited "All societies or clubs calling themselves Spencean or Spencean Philanthropists, and all other societies or clubs, by whatever name or description the same are called or known". ${ }^{25}$ More attacked Spence as a well-known figurehead of radicalism.

Although it is unsurprising that More had heard of Spence, there are also personal and professional links underpinning their careers. Both worked closely with Newcastle printer and engraver Ralph Beilby. In May 1795 More wrote to Beilby for assistance in undertaking the "circulation of the Repository Tracts at Newcastle"; she asks for "any hints respecting this business - also giving full directions about sending the Tracts, and naming any other probable places of circulation" ${ }^{26}$ One of Beilby's surviving business ledgers contains a record relating to a 'H. More'. If the entry refers to Hannah More, then there is evidence that Beilby fulfilled More's request in May 1795, and that he sent a number of woodcuts to her as early as $1792 .{ }^{27}$ It suggests that More considered Beilby 
to be a close business associate in the 1790s during the design and distribution of the Cheap Repository Tracts.

Spence also had a close working relationship with Beilby through his friendship with notable engraver Thomas Bewick (1753 -1828). Mary Ashraf has tentatively attributed the woodcut that accompanies The History of Robinson Crusoe to Bewick. ${ }^{28}$ The nineteenth century Bewick Collector also makes this attribution. ${ }^{29}$ I would suggest that the later woodcuts in Spence's Robinson Crusoe more closely reflect Bewick's distinctive style (see figure 3).

Other details of Bewick and Spence's association are more certain. Bewick helped to create the unusual typeface for Spence's phonetic dictionary. He recalled how he "cut the letters" and how Beilby "struck them on the matrices for casting his newly invented letters of the alphabet for his "Spelling and Pronunciation Dictionary"'. ${ }^{30}$ It is hard to imagine a more important professional relationship for Spence than one which enabled the publication of his Grand Repository of the English Language (1775). Beilby and Bewick's workshop also assisted in the publication of the reprint of The History of Robinson Crusoe (1782) in Spence's phonic script. ${ }^{31}$ There was a social component to this professional relationship. Both Spence and Beilby were active participants in the cultural life of Newcastle. Beilby was one of the founding members of the Newcastle Philosophical Society. The Society saw Spence first deliver his speech 'Property in Land Every One's Right' which would be published as a pamphlet in 1775 and formed the basis of his political philosophy. The Society expelled Spence for printing his speech "in the manner of a halfpenny ballad, and having it hawked about the streets', and they criticised its "dangerous levelling principles". ${ }^{32}$ The furore that surrounded Spence's publication of his speech directly concerned Beilby, as letters regarding the matter were received in his workshop. ${ }^{33}$ Despite Spence's expulsion, the two men would work in close proximity with each other for years to come. Furthermore, there is evidence of a political connection between the three men; Spence, Beilby and Bewick all walked together to sign a petition against the war with America as soon as news of the outbreak of hostilities had been announced in the streets of Newcastle. ${ }^{34}$ Beilby and Spence were thus both personally acquainted and active participants in eighteenth century Newcastle print and publishing networks.

The fact that in 1795 More was utilising Beilby as a distributor in Newcastle demonstrates that she was engaging with the same people and provincial cultural networks that had helped launch Spence radical career. Moreover, Beilby's connections to Spence and radicalism provide a firm fit with the Bishop of London, Beilby Porteus's advice about the need for the Cheap Repository to recruit radical booksellers: "There is a central set of booksellers that are to the full as mischievous as your hawkers, pedlars and match women, in vending the vilest penny pamphlets to the poor people [...] if therefore we gain any of these miscreants to our side we shall have the most respectable set of booksellers, to dispose of our works". ${ }^{35}$ Beilby, it could be argued , was a suitable candidate.

More was one of the most famous loyalist writers working at the end of the eighteenth century. Moreover, her popular tract Village Politics (1792) proved to be one of the most successful loyalist pamphlets of the decade.$^{36}$ So successful was Village Politics that More initiated her own nationwide literary campaign "to promote good morals among the poor" ${ }^{37}$ This became known as the Cheap Repository for Moral and Religious Tracts 
(1795-1797), one of the largest publishing ventures of the period which marshalled resources to distribute two million tracts by the end of $1795 .{ }^{38}$

These tracts were targeted at a broad and popular audience. Tracts such as 'Patient Joe ; or, the Newcastle Collier' (1795) were produced for regional markets to appeal to local needs and concerns. More was prepared to utilise local distribution networks associated with popular chapbook literature to help facilitate the circulation of the tracts ; as she writes to Charles Middleton in October 1794, "I am getting acquaintance with all the hawkers, pedlars, and matchwomen in town and country". ${ }^{99}$ Accordingly, More designed the tracts to mimic the popular chapbook literature associated with the labouring poor. ${ }^{40}$ Chapbooks were cheap works of literature sold by chapmen across the country in rural as well as urban areas. ${ }^{41}$ They frequently contained decorative woodcuts that illustrated the narrative and helped the works to function as products among communities with varying degrees of literacy. ${ }^{42}$ In working with The Cheap Repository Tracts, More was able to successfully imitate the style as well as the form of circulation associated with popular chapbook literature. ${ }^{43}$

Figure 1

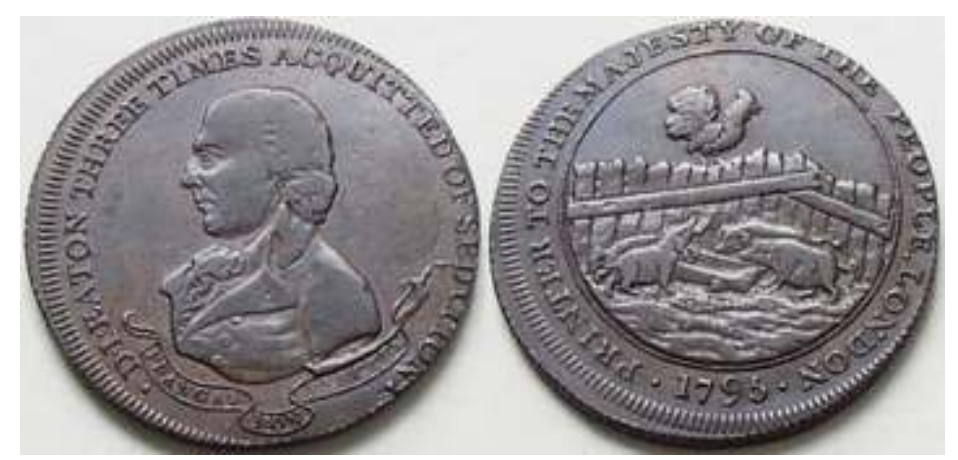

Commemorative coin stuck to celebrate Eaton's acquittal for sedition. Source : http://www.abccoinsandtokens.com/DH.Middlesex.0301.010.RP.html 
Figure 2

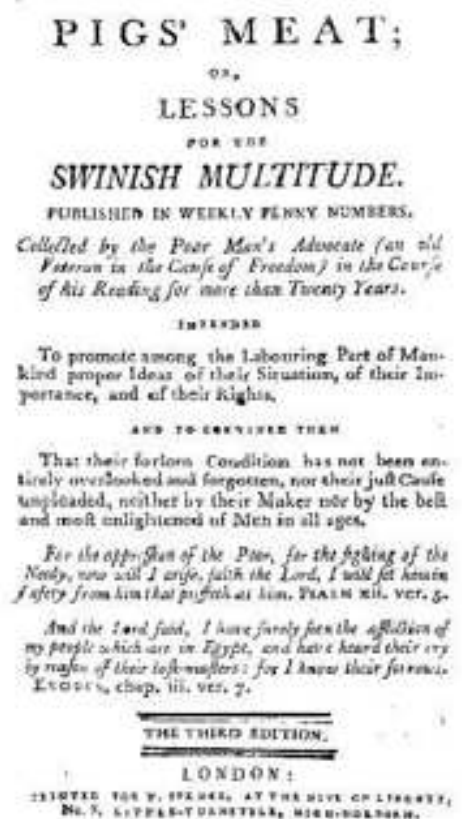

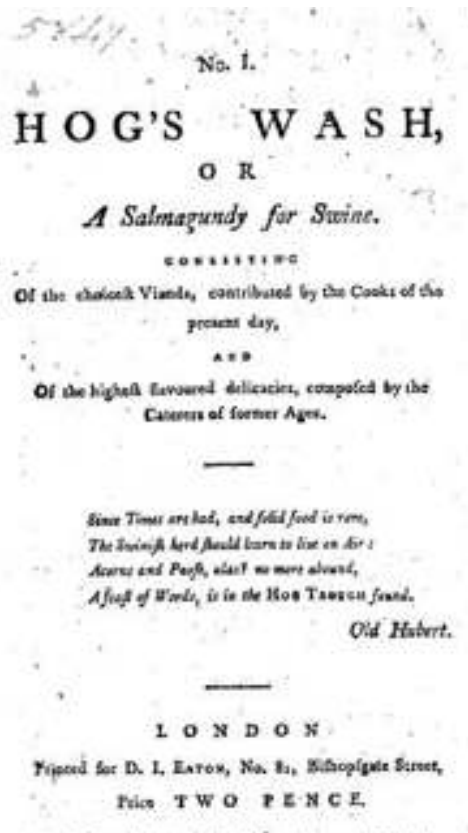

No 11. will be pullinhed on the gth, Otaber.

Figure 3

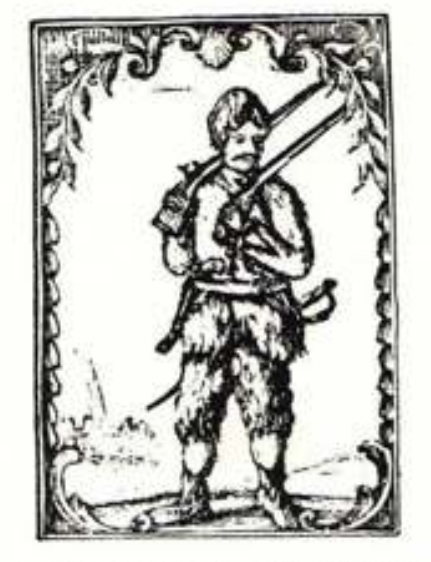

ROBINSON CRUSOE.

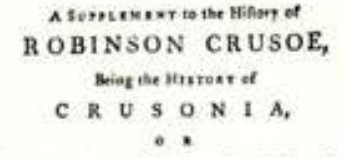

Robinfon Crufoe's Ifland, Dowa to the prefent Time.

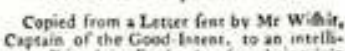

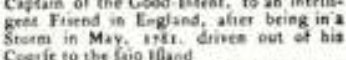

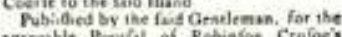

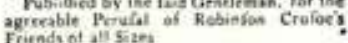
Friends of th

A NeE E D ITIO N.

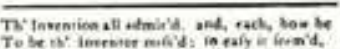

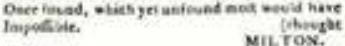

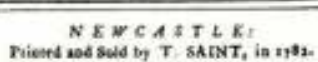
Thice od.

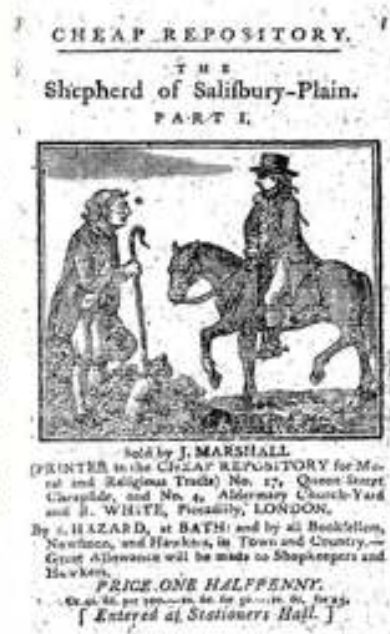




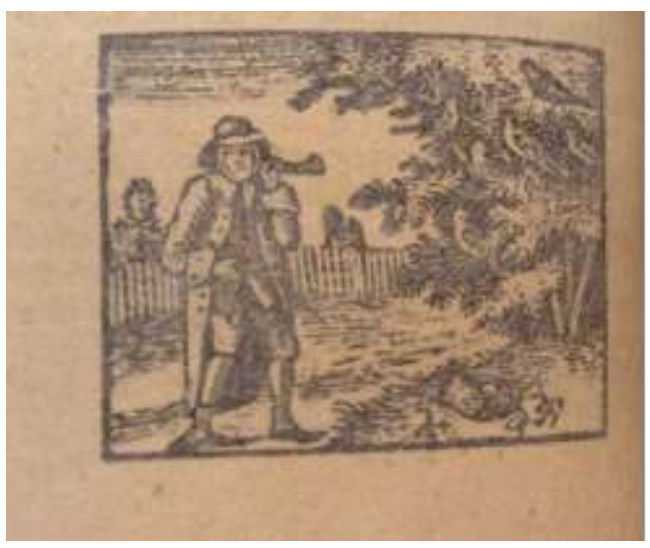

Woodcut illustration from A Supplement to the History of Robinson Crusoe showing designs similar to those by Thomas Bewick. British Library. Shelf mark 1459.a.19.(1.)

The adoption of a chapbook mode was perhaps to be expected of a uniquely well-read and astute loyalist activist such as More, who never missed an opportunity to engage herself with the popular literature that the labouring poor were reading. As More wrote to her close friend Horace Walpole in 1793 :

I wonder if I shall ever live to read a book again that shall cost a shilling. I have lived so long on halfpenny papers, penny cautions, twopenny warnings and threepenny sermons, that I shall never be able to stretch my capacity even to a duodecimo ! $!^{44}$

Given this level of familiarity with popular radical literature, it would have been highly likely that More had a knowledge of Spence. By 1795, the year in which More planned and published the Cheap Repository, Spence had risen to public prominence, working with radical luminaries such as Eaton and Thelwall in London. His trial for sedition had attracted much publicity, and the published account, The Case of Thomas Spence (1792, 1793) had run to two editions. ${ }^{45}$ His weekly penny-periodical Pig's Meat was also a highly influential radical magazine. Furthermore, Spence had been implicated in the Treason Trials of 1794 along with several notable radicals. ${ }^{46}$

At first glance Spence and More may appear to have little in common. However, closer inspection of their work shows a similar engagement with and production of popular political literature. Both authors sought to influence labouring class readers by appropriating plebeian literary cultures to further their divergent political ideologies. Yet, to date, few critics have thoroughly investigated the overlap between conservative and radical cultures, and the shared networks between More and Spence has not been sufficiently examined. ${ }^{47}$

The connections are there. For example, Spence's Supplement to the History of Robinson Crusoe (1782) shares similarities More's own work with Village Politics and the Cheap Repository Tracts. Spence used what was one of the most common chapbook stories of the eighteenth century, Daniel Defoe's Robinson Crusoe (1719). Indeed, unauthorised cheap print editions of Defoe's novel far outnumbered official publications and amounted to over 150 individual chapbooks by the end of the century. ${ }^{48}$ Newcastle was an important regional centre for chapbook production and printed its own versions of Robinson Crusoe. ${ }^{49}$ Chapbook editions provided altered narratives, so they could differ substantially from Defoe's original text..$^{50}$ Spence's version was no exception; his 
adaptation of Robinson Crusoe tells the tale of a new society set up on democratic principles with an emphasis on the common ownership of land..$^{51}$ What is exceptional is the level of overt politicisation that Spence achieves in his work; while other chapbooks produced for labouring class readers could encompass subversive and resistive qualities, none were as explicitly political in their aims and intentions..$^{52} \mathrm{It}$ would be another decade before More would publish chapbook-style literature that contained such an explicit ideological message in her publication Village Politics (1792).

Both A Supplement to the History of Robinson Crusoe and Village Politics (along with later works in the Cheap Repository Tracts) share the use of a dialogue between two characters to convey their political message. More's use of the dialogue form in Village Politics has attracted the attention of a number of critics; Anne Stott, for example, comments that it enables the work to appear "more democratic" than other loyalist tracts. ${ }^{53}$ Moreover, Mark Philp sees Village Politics as a successful application of "the rhetorical complexities and ambiguities of the dialogue form" in its portrayal of two labouring class voices. ${ }^{54}$ Philp commends the fact that More allows the radically minded character Tom to answer back to the loyalist character Jack..$^{55}$ Indeed, Philp suggests that there is hidden radical potential in More's use of the dialogue form :

The very qualities that make Village Politics successful also limit its capacity to make men loyal, since it teaches them standards of assessment alongside its appeal to take the established order on trust. ${ }^{56}$

Philp suggests that the dialogue form in particular could encourage readers to exercise their critical faculties concerning politics in a way that did not cohere with loyalist ideology. Olivia Smith makes a similar argument in The Politics of Language concerning More's production of political literature intended for the poor to read that preached the morality of ignoring political texts. ${ }^{57}$ More's use of the dialogue form in Village Politics displays many of these internal contradictions and unintentional political ambiguities.

The same is not the case with Spence's use of the dialogue form in the History of Robinson Crusoe. Spence's dialogue consists of a conversation between a sceptical 'Captain' and 'Mann', an inhabitant of Crusoe's island. The two discuss the growth of the society that followed Crusoe's establishment of a successful colony. The conversation between Captain and Mann parallel the discourse between Jack and Tom in Village Politics. As Stott and Philp have contended, Village Politics contains a more 'democratic' form of conversation than the often vertical interchange of argument that could characterise some conservative texts. ${ }^{58}$ This is a feature that also characterises Spence's text. Though Spence has Mann espouse the virtues of his views on society, Captain is permitted to question and query his ideas quite liberally. For instance, Captain is highly sceptical of the removal of the landlord and tenant system :

Capt : But I am afraid Landlords are as much the Produce of all Lands, as other Kinds of Monsters are of the Nile, and it will be difficult to part or keep them long asunder.

Mann: I agree with you. that where there are Men, there will be Landlords, so Heaven hath ordained; but then, we have so provided, that we are all Landlords, and yet no Giants; so that the least Change in our excellent System, would effect the Interest of every one, which makes every one a Guardian to the Commonweal. Capt : Very true : But I have heard of Bribery doing mischievous Things to Societies, and even overturning some; for it will make Men vote, fight, or do any Thing against the Interests both of the present Generation, and all that are to come, which makes me tremble for your State. ${ }^{59}$ 
This form of 'democratic' dialogic interchange is very similar to More's work in Village Politics. The Captain's concerns are answered by Mann but he then immediately contends the issue of bribery and further questions the reform of society that Mann presents. These were real and pressing issues at a time when bribery was an essential component of Britain's limited democracy ${ }^{60}$ This form of plausible questioning by the Captain is analogous to that performed by Tom in Village Politics. Tom puts forth questions to Jack that genuinely engage with contemporary issues of political debate :

Tom : [...] have you read the Rights of Man?

Jack : No, Not I. I have rather by half have read the Whole Duty of Man. I have but little time for reading, and such as I should therefore only read a bit of the best.

Tom : Don't tell me of those old fashioned notions. Why should not we have the same fine things they have got in France? I'm for a Constitution, and Organization, and Equalization.

$[\ldots .$.

Jack : You might as well cry for the moon. There's nothing perfect in this world, take my word for it : tho' Sir John says, we come nearer to it than any country in the world ever did.

Tom : I don't see why we are to work like slaves, whilst others roll about in coaches, feed on the fat of the land, and do nothing. ${ }^{61}$

31 Issues concerning the constitution, equality, and aristocratic privilege were contentious subjects in the $1790 \mathrm{~s} .{ }^{62}$ By permitting Tom to voice genuine concerns, More presents believable characters that a plebeian readership would, perhaps, more readily associate with. What is also apparent, however, is that Spence had achieved something very similar a decade before More.

The interchange of dialogue in Village Politics encourages what Philp terms a consideration of 'standards of assessment' that could, potentially, lead to radical conclusions. However, if "the rhetorical complexities and ambiguities of the dialogue form" present a problem to the loyalist ideology that More wishes to present, they only benefit the reformist argument which Spence foregrounds with his own work. ${ }^{63}$ This is because Spence's text is directly concerned with questioning and opening up ideological fissures in contemporary British society, whilst More's motivation is to close them down. Furthermore, Spence's text, originating in the 1780s, did not operate within the same context of intense popular political debate that characterized the 1790 s and therefore necessitated a form that would engender wider discussion. If the dialogue form seems more suited to Spence's work then this is because he has selected a literary form that strongly relates to his political ambitions.

of course, both texts' use of dialogue is clearly structured in a way that preconditions our sympathy as readers to fall on the side of one particular character. For instance, the answers that Captain and Tom provide are there, in part, to set up a convincing explanation from either Jack or Mann. For example, Tom's desire for a 'Constitution, and Organization, and Equalization' enables Jack to critique a (remarkably Spencean) society based on the equal ownership of land:

[...] in the general division, our new rulers were to give us half an acre of ground apiece; we could to be sure raise potatoes on it for the use of our families; but as every other man would be equally busy in raising potatoes for his family, why then you see if thou wast to break thy spade, I should not be able to mend it. ${ }^{64}$

In a similar fashion The History of Robinson Crusoe utilises the character of the Captain to voice scepticism in a way that enables a persuasive response. For instance, the issue of "Bribery doing mischievous Things to Societies" is neatly and convincingly answered 
by Mann through the proposal of a secret ballot: "For you must understand we never vote but by Ballot, or in a secret Manner, either in Parochial or Parliamentary Business". ${ }^{65}$ These structural similarities are also reflected in the lengthy answers that both Mann and Jack provide. The interjections that Tom and Captain present are few in comparison and essentially function to punctuate the anecdotes, evidence, and polemics put forth by Mann and Jack. It is clear then, that a formal comparison of both Village Politics and a History of Robinson Crusoe demonstrate similarities between the two texts.

There are also visual similarities between The History of Robinson Crusoe and More's work with the Cheap Repository Tracts (see figure 4). Spence's text features a familiar image of Crusoe standing proudly in furs with a rapier on his belt and rifles at the ready. This type of cheap woodcut was a common feature in chapbook literature that was popular amongst communities with varying degrees of literacy. ${ }^{66}$ More also used similar designs in her own pamphlets. As with other entries in the Cheap Repository Tracts, The Shepherd of Salisbury Plain (1795) features a woodcut providing a simple illustration of the story. Both texts use the visual features of chapbook literature in order to better situate their work in a familiar format for a popular readership.

It is not possible to say for certain that More wished to work with Beilby because of his experience working with vernacular literature and his connections to Spence, but her personal attempt to recruit his aid make such circumstances tenable. Furthermore, the similarities between the use of political dialogue in Village Politics and the History of Robinson Crusoe show Spence anticipating what More would achieve in the 1790s with a very different political end in mind. In addition to this, both authors' use of chapbook inspired visual styling, stories and content present an overlap in terms of design. We can say with more certainty that Spence's success with Pig's Meat assisted the publication of Eaton's Hog's Wash or Politics for the People. Spence's opening letter and extract show how Eaton employed a similar model to Spence in terms of a popular and saleable radical miscellany. The weekly publication, cheap price, and varied contents of both magazines demonstrate they were the product of a similar print culture. It is clear, therefore, that Spence's work and reputation had a considerable impact on radical publishing in the post-revolutionary period. The connections between radical writers and the intersections between radicals and loyalists are more deeply rooted and more complex than has often been considered. Recovering Spence's networks and connections helps to generate a more rounded picture of the literary and political culture of the 1790s.

\section{BIBLIOGRAPHY}

Ashraf, P. M. The Life and Times of Thomas Spence. Newcastle : Frank Graham, 1983.

Bewick, Thomas. A Memoir of Thomas Bewick, Written by Himself. Newcastle : Robert Ward, 1862. 
The Bewick Collector : a Supplement to a Descriptive Catalogue of the Works of John and Thomas Bewick. London : L. Reeve and Co. 1868.

Bonnett, Alastair. “The Discovery of Thomas Spence's Lecture : Property in Land Every One's Right." Labour History Review, 74, 1, (2009), 134-136.

Bonnett, Alastair and Armstrong, Keith (eds.). Thomas Spence: The Poor Man's Revolutionary. London : Breviary Stuff Publications, 2014.

Butler, Marilyn. Burke, Paine, Godwin, and the Revolution Controversy. Cambridge : Cambridge University, 1998.

Claeys, Gregory. Thomas Paine; Social and Political Thought. Winchester : Unwin Hymen, 1989.

Davis, Michael T. “'“I can bear punishment” : Daniel Isaac Eaton, radical culture and the rule of law, 1793-1812." Criminal Justice History, 18, (2003) : 89-106.

Dickinson, William. Burn, Richard and Williams, John (eds.) The Justice Law of the Last Five Years : Viz. from 1813 to 1817. London : Clark and Sons, 1818.

Dimmock, Matthew and Hadfield, Andrew. Literature and Popular Culture in Early Modern England. Farnham : Ashgate Publishing, 2009.

Downey, Edmund “An Unpublished Letter from Hannah More to Ralph Beilby : Radical Connections and Popular Political Literature" Notes and Queries 61 (2014) : 504-507.

Eaton, D. I. The Address of the British Convention Assembled at Edinburgh, November 19, 1793. London : D. I. Eaton, 1793.

Ford, Charles Howard. Hannah More : A Critical Biography. New York : P. Lang, 1996.

Fox, Charles. The Life of the Right Honourable Charles James Fox. London : James Cundee, 1807.

Frances, Mary Thomson. Newcastle Chapbooks in Newcastle upon Tyne University Library, (Hull, Oriel Press, 1969.

Garrard, John. Democratisation in Britain : Elites, Civil Society, and Reform since 1800. Gordonsville : Palgrave Macmillan, 2002.

Goodrich, Amanda. Debating England's Aristocracy in the 1790s. Woodbridge : Boydell Press, 2005.

Gilmartin, Kevin. “Study to Be Quiet' : Hannah More and the Invention of Conservative Culture in Britain." ELH, 70.2 (2003) : 493-540.

Letter from Bishop Porteus to Hannah More, William Roberts, Memoirs of the Life and Correspondence of Mrs. Hannah More, II. London : Harper and Brothers, 1834.

Mackenzie, Eneas. Descriptive and Historical Account of the Town and Country of Newcastle. Newcastle : Mackenzie and Dent, 1827.

McCue, Daniel Lawrence, Jnr. “Daniel Isaac Eaton and Politics for the People.” Unpublished doctoral thesis, Columbia University, 1974.

Scrivener, Michael. Seditious Allegories :John Thelwall and Jacobin Writing. Pennsylvania :

Pennsylvania University Press, 2001.

More, Hannah. "Hannah More to Charles Middleton" in Chatterton, Lady Georgiana (ed.) Memorials Personal and Historical of Admiral Lord Gambier. London : Hurst and Blackett, 1861.

More, Hannah. The Works of Hannah More : A New Edition in Eighteen Volumes, Volume IV Essay and Tracts. London : T. Cadell W. Davies, 1818. 
More, Hannah. The Yale Edition of Horace Walpole's Correspondence with Hannah More et al. Ed. W. S. Lewis. London : Yale University Press, 2000.

More, Hannah. Village politics. Addressed to all the Mechanics, Journeymen, and Day Labourers, in Great Britain. London : C. Rivington, 1793.

Newcastle Chronicle, 25 November, 1775.

O'Malley, Andrew. Children's Literature, Popular Culture, and Robinson Crusoe. Basingstoke : Palgrave Macmillan, 2012.

Penny Satirist, The. $62: 23$ June, 1838.

Philp, Mark. "Vulgar Conservatism." English Historical Review 110 (1995) : 42-69.

Eaton, Daniel. Politics for the People ; or, A Salmagundy for Swine. London : D. I. Eaton, 1793.

Powell, Manushag. Performing Authorship in Eighteenth-century English Periodicals. Maryland : Bucknell University Press, 2012.

Scrivener, Michael. "Literature and Politics." In The Cambridge Companion to English Literature, 1740-1830. Ed. Thomas Keymer and Jon Mee. Cambridge : Cambridge University Press, 2004.

Smith, Olivia. The Politics of Language. Oxford : Oxford University Press, 1984.

Spence, Thomas. A Supplement to the History of Robinson Crusoe, being a History of Crusonia, or Robinson Crusoe's Island, Down to the Present Time. Newcastle : T. Saint, 1782.

Spence, Thomas. The Case of Thomas Spence : Bookseller, the Corner of Chancery-Lane, London. London : T. Spence, 1792.

Spufford, Margaret. Small Books and Pleasant Histories : Popular Fiction and Its Readership in Seventeenth-Century England. Cambridge : Cambridge University Press, 1981.

St Clair, William. The Reading Nation in the Romantic Period. Cambridge : Cambridge University Press, 2004.

Stott, Anne. Hannah More, the First Victorian. Oxford : Oxford University Press, 2003.

Thompson, E. P. The Making of the English Working Class, Penguin : Harmondsworth, 1968.

Tyne and Wear Archive, Beilby and Bewick, Accession 1269, MF 2374.

Uglow, Jenny. Nature's Engraver : A Life of Thomas Bewick. London : Faber and Faber, 2006.

White, Simon. J. Romanticism and the Rural Community. Basingstoke : Palgrave, 2014.

Wood, Marcus. Radical Satire and Print Culture :1790-1822. Oxford : Clarendon Press, 1994.

\section{NOTES}

1. See Bonnett, Alastair and Armstrong, Keith (eds.). Thomas Spence: The Poor Man's Revolutionary. London: Breviary Stuff Publications, 2014.

2. Bonnet, Alistair. “The Discovery of Thomas Spence's Lecture: Property in Land Every One's Right" in Labour History Review, 74, 1, (2009). 134-136.

3. Downey, Edmund. "An Unpublished Letter from Hannah More to Ralph Beilby: Radical Connections and Popular Political Literature" in Notes and Queries 61, (2014): 504-507.

4. Thompson, E. P. The Making of the English Working Class. Penguin: Harmondsworth, 1968. 105. 
5. Claeys, Gregory. Thomas Paine; Social and Political Thought. Winchester: Unwin Hymen, 1989. 120; Davis, Michael T, “ "I can bear punishment": Daniel Isaac Eaton, Radical Culture and the Rule of Law, 1793-1812" in Criminal Justice History, 18, (2003) 89-106, 90.

6. For a detailed description of the various publications printed by Eaton see "Early Pamphlets and First Legal Trials 1793-1794" 45-55 and "New publishing Ventures 1794-1796" in McCue, Daniel Lawrence, "Daniel Isaac Eaton and Politics for the People". Unpublished doctoral thesis, Columbia University, 1974; An advertisement in The Address of the British Convention lists 19 individual publications by Eaton in 1793 alone. Eaton, D.I. The Address of the British Convention Assembled at Edinburgh, November 19, 1793. London: D.I Eaton, 1793. 2.

7. Politics for the People; or, A Salmagundy for Swine. London: D.I. Eaton, 1793.

8. McCue, Daniel Lawrence. "Daniel Isaac Eaton and Politics for the People". Unpublished doctoral thesis, Columbia University, 1974. 549.

9. For the best account of Eaton's trial see Scrivener, Michael. Seditious Allegories: John Thelwall and Jacobin Writing. Pennsylvania: Pennsylvania University Press, 2001. 112-118.

10. Ibid.

11. Ashraf, P.M. The Life and Times of Thomas Spence. Newcastle: Frank Graham, 1983. 153.

12. Eaton's working relationship with Spence is noted by $P$. M. Ashraf on two occasions in The Life and Times of Thomas Spence though a literary influence is not examined see 48-50; Daniel McCue's otherwise well-researched thesis "Daniel Isaac Eaton and Politics for the People" does not cite Spence as an influence on Eaton's periodical. Likewise, E.P. Thompson celebrates Eaton work but does not note an influence from Spence see The Making of the English Working Class. 105; Marilyn Butler notes that Politics for the People and Pig's Meat are "similar weekly journals" but does not cite one as an influence upon the other, see Burke, Paine, Godwin, and the Revolution Controversy. Cambridge: Cambridge University, 1998. 185.

13. Powell, Manushag. Performing Authorship in Eighteenth-century English Periodicals. Maryland: Bucknell University Press, 2012. 37.

14. St Clair, William. The Reading Nation in the Romantic Period, 'Appendix 8, Periodicals'. Cambridge: Cambridge University Press, 2004). 572-574.

15. Ibid., 572-573.

16. Politics for the People, I, September 1793. London: D.I. Eaton, 1793. 2.

17. Ibid.

18. The Malecontent. A letter from an Associator to Francis Plowden. London: J. Swell, 1794. 107.

19. Fox, Charles. The Life of the Right Honourable Charles James Fox. London: James Cundee, 1807. 220.

20. Politics for the People, I, September 1793. 2.

21. Scrivener, Michael. 'Literature and Politics' in The Cambridge Companion to English Literature, 1740-1830, Keymer, Thomas and Mee, Jon (eds.) Cambridge: Cambridge University Press, 2004. 50.

22. Ashraf, P.M. The Life and Times of Thomas Spence. 50.

23. See 'Fair Words and Foul Meanings' and 'The Delegate' in The Works of Hannah More: A New Edition In Eighteen Volumes, Volume IV Essay and Tracts. London: T. Cadell W. Davies, 1818. 87, 448.

24. Ibid.,448.

25. Dickinson, William. Burn, Richard and Williams, John (eds.) The Justice Law of the Last Five Years: Viz. from 1813 to 1817. London: Clark and Sons, 1818. 552.

26. Ibid., 3.

27. Tyne and Wear Archive, Beilby and Bewick, Accession 1269, MF 2374.

28. Ashraft, P. M. The Life and Times of Thomas Spence. 153.

29. The Bewick Collector: a Supplement to a Descriptive Catalogue of the Works of John and Thomas Bewick. London: L. Reeve and Co. 1868. 9.

30. Bewick, Thomas. A Memoir of Thomas Bewick Written by Himself. Newcastle: Robert Ward, 1862. 73. 
31. Ashraft, P.M. The Life and Times of Thomas Spence. 153.

32. Mackenzie, Eneas. Descriptive and Historical Account of the Town and Country of Newcastle. Newcastle: Mackensie and Dent, 1827; Newcastle Chronicle, 25 November, 1775.

33. Uglow, Jenny. Nature's Engraver: A Life of Thomas Bewick. London: Faber and Faber, 2006. 107.

34. Ibid., 82.

35. Letter from Bishop Porteus to Hannah More, William Roberts, Memoirs of the Life and Correspondence of Mrs. Hannah More, II. London: Harper and Brothers, 1834. 427.

36. Stott, Anne. Hannah More, the First Victorian. Oxford: Oxford University Press, 2003. 310.

37. Letter from Hannah More to William Wilberforce, 1795 quoted in Stott, Anne, Stott Hannah More: The First Victorian. 170.

38. Ibid., 176.

39. More, Hannah. 'Hannah More to Charles Middleton' in Chatterton, Lady Georgiana (ed.) Memorials Personal and Historical of Admiral Lord Gambier. London: Hurst and Blackett, 1861. 169.

40. Ibid., 169-191; Kevin Gilmartin," "Study to Be Quiet": Hannah More and the Invention of Conservative Culture in Britain' ELH, 70.2 (2003). 493-540; Charles Howard Ford, Hannah More: A Critical Biography. New York: P. Lang, 1996.

41. Spufford, Margaret. Small Books and Pleasant Histories: Popular Fiction and Its Readership in Seventeenth-Century England . Cambridge: Cambridge University Press, 1981. 2.

42. Ibid., 3.

43. Philp, Mark. 'Vulgar Conservatism' English Historical Review, 110 (1995). 42-69. 62.

44. More, Hannah. The Yale Edition of Horace Walpole's Correspondence with Hannah More et al. Lewis, W.S. (ed.) London: Yale University Press, 2000. 373-376.

45. Spence, Thomas. The Case of Thomas Spence: Bookseller, the Corner of Chancery-Lane, London. London: T. Spence, 1792.

46. Wood, Marcus. Radical Satire and Print Culture: 1790-1822. 90.

47. Comparisons between Spence and More have notably been made by Olivia Smith in terms of their innovative appropriation of plebeian literary forms for political proposes, The Politics of Language. Oxford: Oxford University Press, 1984. 90. More recently Simon J. White has considered both figures for their shared focus on poverty in rural communities. 'The Cottager and 1790s Political Polemic' in Romanticism and the Rural Community. Basingstoke: Palgrave, 2014. 14-40. Criticism, however, has not yet proposed a direct interchange of influence or shared networks of publication between the two authors.

48. O'Malley, Andrew. Children's Literature, Popular Culture, and Robinson Crusoe. Basingstoke: Palgrave Macmillan, 2012. 77.

49. Frances, Mary Thomson. Newcastle Chapbooks in Newcastle upon Tyne University Library. Hull, Oriel Press, 1969. 6; O'Malley, Andrew. Children's Literature. 81.

50. Ibid., 78.

51. Spence, Thomas. A Supplement to the History of Robinson Crusoe, being a History of Crusonia, or Robinson Crusoe's Island, Down to the Present Time. Newcastle: T. Saint, 1782.

52. A number of these versions are referenced by O'Malley in Children's Literature, Popular Culture, and Robinson Crusoe in chapter 3 "Poaching on Crusoe's Island: Popular Reading and Chapbook literature". 76-102.

53. Anne Stott. Hannah More, the First Victorian. 139.

54. Philp, Mark. 'Vulgar Conservatism'. 62.

55. Ibid.

56. Ibid., 63.

57. Smith, Olivia. The Politics of Language; 1791-1819. 71.

58. Stott, Anne. Hannah More: The First Victorian. 139; Philp, Mark. 'Vulgar Conservatism'. 62.

59. Spence, Thomas. A Supplement to the History of Robinson Crusoe, being a History of Crusonia, or Robinson Crusoe's Island, Down to the Present Time. Newcastle: T. Saint, 1782. 19. 
60. Garrard, John. Democratisation in Britain: Elites, Civil Society, and Reform since 1800. Gordonsville: Palgrave Macmillan, 2002. 23.

61. More, Hannah. Village politics. Addressed to all the Mechanics, Journeymen, and Day Labourers, in Great Britain. London: C. Rivington, 1793. 7-9.

62. Goodrich, Amanda. Debating England's Aristocracy in the 1790s, Woodbridge: Boydell Press, 2005. 75.

63. Philp, Mark. 'Vulgar Conservatism'. 60.

64. More, Hannah. Village Politics. 7.

65. Thomas. Spence. A Supplement to the History of Robinson Crusoe. 19.

66. Dimmock, Matthew and Hadfield, Andrew. Literature and Popular Culture in Early Modern England. Farnham: Ashgate Publishing, 2009. 61.

\section{ABSTRACTS}

This article examines Spence's connections with contemporary authors and political activists. It considers Spence's relationship with the notable political reformer and fellow London Corresponding Society member Daniel Isaac Eaton (1753-1814), the evangelical conservative Hannah More (1745-1833), and the Newcastle engraver and publisher Ralph Beilby (1744-1817). Firstly, by considering the under-examined literary networks that connected Spence and Eaton in the metropolitan world of 1790 s radicalism this article draws attention to the similar design and publication of Spence's One Pennyworth of Pig's Meat; or, Lessons for the Swinish Multitude (1793-1795) and Eaton's Hog's Wash, or a Salmagundy for Swine, (1793-1795). These works are read alongside evidence of a professional and literary relationship that connected the two authors. Additionally, this article outlines Spence's relationship with Ralph Beilby, a figure who helped Spence create the unique typeface for his Grand Repository of the English Language (1775). Next, the article explores the literary network that connected Beilby and Hannah More through the distribution of the Cheap Repository Tracts (1795). Lastly, there is a consideration of the striking correspondences that exist between Spence and Hannah More, not only through their professional connection to Beilby, but also between their popular political works which aimed at a broad labouring class audience.

Cet article aborde les liens qu'entretenait Spence avec les auteurs et militants politiques de son époque. Il s'intéresse à la relation entre Spence et le réformateur politique Daniel Isaac Eaton (1753-1814) ainsi qu'à celle qui le liait à la réformatrice conservatrice évangélique Hannah More (1745-1833), ou encore au graveur Ralph Beilby (1744-1817). Dans un premier temps, il traite de réseaux littéraires peu étudiés témoignant du lien entre Spence et Eaton au sein du monde radical londonien des années 1790 . Ceci invite à insister sur les similitudes de présentation entre One Pennyworth of Pig's Meant; or, Lessons for the Swinish Multitude (1793-1795) de Spence et Hog's Wash, or a Salmagundy for Swine (1793-1795) de Eaton. Ces deux œuvres viennent confirmer l'existence d'une collaboration professionnelle et littéraire entre les deux auteurs. En outre, cet article étudie le lien entre Spence et Beilby, un graveur qui aida Spence à créer la police de caractère unique destinée à son Grand Repository of the English Language (1775). Enfin, il s'attache au réseau littéraire entre Beilby et Hannah More au travers de la distribution des Cheap Repository Tracts (1795). Enfin, une dernière partie se penchera sur les correspondances frappantes entre Spence et More, non seulement au travers des liens qu'ils entretenaient avec Beilby, mais 
également en se plongeant dans leurs œuvres politiques, qui s'adressaient à un large lectorat ouvrier.

INDEX

Mots-clés: réseaux, connexions littéraires, littérature populaire, radicalisme, loyalisme

Keywords: networks, literary connections, popular literature, radicalism, loyalism

\section{AUTHOR}

EDMUND DOWNEY

University of Nottingham

edmund.downey@nottingham.ac.uk 